\title{
Türkiye'de Bölgesel Farklılaşmadan Orta Gelir Tuzağına Çıkarımlar
}

\author{
Inferences from Regional Diversification to Middle Income Trap in Turkey \\ Ümit K. SEYFETTININĞLU' 1 \\ Mehmet ZANBAK ${ }^{2}$
}

Geliş tarihi: 06.01.2017, Kabul tarihi: 30.03.2017, Basım tarihi: 10.06.2017

\section{Özet}

Verimlilik düzeyindeki azalmaya bağlı olarak gelişmekte olan ülkelerde, kişi başına düşen gelirin artış hızının giderek yavaşlaması ve gelir seviyesinin belirli bir düzeyde sabitlenmesi "orta gelir tuzağı" olarak adlandırılmaktadır. Verimlilikte görülen azalma ise kentlerde yığılan sermayenin giderek olgunlaşan teknoloji kullanması, beşeri sermayenin gelişmemesi ve ekonominin vasıfsız işgücü yoğun bir istihdam yapısına dönüşmesi ile açıklanmaktadır. Konu Türkiye açısından incelendiğinde, uzun süredir oldukça düşük seyreden sabit sermaye yatırımlarının, sanayileşmiş ülkelere kiyasla yukarıda sıralananlara ek bir faktör olarak ortaya çıktı̆̆1 görülmektedir. Bununla birlikte, Türkiye'deki bölgesel gelişmişlik farklılıkları,göreli olarak yoksul bölgelerin ucuz işgücü ve hammadde ile daha üretken ve zengin bölgeleri beslemesine, böylece bölgesel farklılaşmanın bir kısır döngü haline gelmesine yol açmaktadır.

Bu çalışma, özellikle beşeri sermaye alanında bölgesel farklılaşma ile göreli olarak düşük seyreden sabit sermaye yatırımlarının orta gelir tuzağına etkilerini, bölgesel katma değer üzerinde odaklanarak incelemektedir. Çalışmada, Düzey 2 bölgelerine ilişkin panel veri kullanılırken ekonometrik modeller sabit etkili panel ve coğrafi olarak ağırlıklandırılmış regresyon tekniği ile tahmin edilmektedir. Bulgular, işyeri ölçeği, mesleki ve teknik okul sayıları ve öğretmen başına düşen öğrenci sayısının Düzey 2 bölgelerinde gayri safi katma değerdeki değişimi açıladığını ve bu üç faktörün 20042011 döneminde etkisini sürdürdügünü göstermektedir.

Anahtar Kelimeler: Verimlilik, Bölgesel Farklılașma, Orta Gelir Tuzağı, Coğrafi Olarak Ağtrlkklandirlmış Regresyon.

JEL Kodlar1: C31, C33, D12, J24

\begin{abstract}
The fall in growth rate of per capita income in relation to non-increasing productivity levels after a certain threshold in developing countries is called "middle income trap". In most cases, the fall in productivity is explained by the matured technology used in accumulated capital in urban areas, by the limited qualifications of human capital and by the transformation of industries into a more unqualified labor abundant structure. Analysing this issue from the perspective of Turkish

\footnotetext{
1 Akdeniz Üniversitesi, İktisadi ve İdari Bilimler Fakültesi, İktisat Bölümü, Yrd. Doç. Dr. umitk@akdeniz.edu.tr

2 Akdeniz Üniversitesi, Kumluca MYO, Yrd. Doç. Dr.

mehmetzanbak@akdeniz.edu.tr
} 
economy, another factor that arose to explain the trap was the relatively limited increase in fixed capital investment for long years with respect to industrialized countries. Besides, the regional diversification in terms of development level in Turkey causes the "trap" to turn into a vicious circle as in this fragmented structure of national economy, relatively more productive and richer regions are fed by the cheap labor force and raw materials of poor regions.

In this study, impact of particularly the regional diversification in human capital and relatively low fixed capital investment on middle income trap are analyzed by focusing on regional value added. In the analyses, a panel data set at NUTS 2 level was used and the econometric analyses were estimated by fixed-effect panel and geographically weighted regression. Hence, while the relative significance of regional diversification in human capital and fixed capital investment is derived, relevant messages were created for policy makers at NUTS 2 level by basing on empirical evidence. Findings provide the information that production scale, number of vocational and technical schools and number of students per teacher explain the variation in per capita gross value added in NUTS 2 level regions and the effects of these factors persisted in the period between 2004-2011.

Keywords: Productivity, Regional Diversification, Middle Income Trap, Geographically Weighted Regression.

JEL Codes: C31, C33, D12, J24

\section{Giriş}

Günümüzde hem politika yapıcılarının hem de akademik yazının üzerinde önemle durduğu ekonomik sorunların başında "gelişmekte olan ülkelerin belli bir eşikten sonra gelir ve buna bağlı olarak refah artışı sağlayamaması ve hatta bu göstergelerdeki negatif ya da durağan değişikliğin olması" yer almaktadır.Bu sorun "orta gelir tuză̆g" olarak adlandırlmaktadır. Orta gelir tuzağı, verimlilik düzeyindeki azalmaya bağlı olarak gelişmekte olan ülkelerde kişi başına düşen gelirin artış hızının giderek yavaşlaması ve seviyenin belirli bir düzeyde sabitlenmesi olarak tanımlanmaktadır.Sorunun temelini orta gelir tuzağında bulunan bir ülkenin gelişmiş ülkeler kategorisine geçememe durumu oluşturmaktadır.

$\mathrm{Bu}$ çalışma, özellikle beşeri sermaye alanında ortaya çıkan bölgesel farklılaşma ile göreli olarak düşük seyreden sabit sermaye yatırımlarının orta gelir tuzağına etkilerini bölgesel katma değer üzerine odaklanarak incelemeyi amaçlamaktadır. Çalışmada, Düzey 2 bölgelerine ilişkin panel veri kullanılırken, ekonometrik modeller sabit etkili panel ve coğrafi olarak ağırlıklandırılmış regresyon tekniği ile tahmin edilmektedir. Çalışmada ilk olarak ülkelerin neden orta gelir tuzağına girdikleri tartışılmaktadır. İkinci bölümde konuyla ilgili yazın araştırması yer almaktadır. Çalısmanın üçüncü bölümünde ise veri seti ve tahmin edilecek model tanitilarak kullanılan ekonometrik modellerin bulguları tartışılmaktadır. 


\section{Orta Gelir Tuzağı}

Eichengreen vd.(2011) göre yıllık ortalama kişi başı geliri 16 bin doları aşan ülkeler orta gelir seviyesinin üzerinde gelire sahip ülkeler sinıfinda yer almakta ve üst gelir grubu olan yüksek gelirli ülkeler kategorisine dahil olmaktadır. Araştırmacılar aynı çalışmada orta gelir sınırını fert gelirinin ABD'nin fert gelirinin \%58'ine, imalat sanayi gelirinin ve istihdamının ise toplam gelir ve istihdam içindeki payının \%23'üne ulaşması șeklinde de ifade etmektedir. Orta gelir düzeyi ölçüsü olarak ABD'nin kişi başına gayri safi yurtiçi hasılasına (GSYH) dayanan bu tanımların yanı sıra Dünya Bankası'nın kişi başına gelire göre yaptı̆̆ı sınıflandırma da ilgili yazındaki yerini almıştır. Dünya Bankası'nın 2013 ylı Dünya Kalkınma Raporu'nda ekonomiler şu şekilde sinıflandırılmaktadır (World Bank, 2013):

Tablo1. Dünya Bankası'nın Gelir Düzeyine Göre Ülke Ekonomileri Siniflamasi

\begin{tabular}{ll}
\hline Ekonomiler & Kişi Başına Yillk Ortalama Gelir \\
\hline Düşük Gelirli Ekonomiler & 1.035 dolar altı \\
Orta Gelirli Ekonomiler & $1.036-12.615$ dolar arası \\
-Alt Orta Gelirli Ekonomiler & $1.036-4.085$ dolar aras1 \\
-Üst Orta Gelirli Ekonomiler & 4.086-12.675 dolar arası \\
Yüksek Gelirli Ekonomiler & 12.616dolar aras1 \\
\hline
\end{tabular}

Kaynak: World Bank, World Development Report 2013.

Bu sınıflandırmayagöre 4.086-12.675 dolar arası kişi başı yıllık ortalama gelir elde eden ve Türkiye'nin de içerisinde bulunduğu ülkelerüst orta gelirli ekonomiler arasında yer almaktadır. Dünya Bankası, yüksek gelirli ekonomilerin altında olan söz konusu ülkeleri, bu durumda kaldıkları süreyi de gözeterek,orta gelir tuzağına yakalanmış kabul etmektedir.

Felipevd.'nin (2012) çalışmalarında orta gelir tuzağının eşiğini belirlerken kullandıkları tespit yöntemleri Dünya Bankası'nın sınıflandırmasına benzerdir. Araştırmacılar 7.250-11.750 dolar arasında kişi başına geliri olan ülkeleri yüksek orta gelirli ülkeler olarak tanımlamıştır. Bir başka ifadeyle, yüksek gelirli ekonomilere geçiş olan 11.750 dolar seviyesini orta gelir tuzağının eşiği olarak kabul etmişlerdir. Ayrıca, en az gelişmişlik seviyesine sahip düşük gelirli ekonomilerin sermaye birikimlerinin yetersiz olduğunu da vurgulayan araştırmacılar,gelir seviyesinin savaş, kıtlık ve kuraklık gibi olumsuzluklar tarafindan da etkilendiğini belirtmişlerdir. Ancak milli gelir içerisindeki sermaye yatırımlarının payı ve dışa açılık derecesi arttıkça ülkelerin gelişmişliklerinin olumlu yönde değiştiği de araştırmacıların bulguları arasında yer almıştır. 
Gelişme yolundaki ülkelerde sanayileşmeyi takip eden birkaç yll süresince ortaya çıkan hızlı gelir artışı,sonraki dönemlerde verimlilik kaybıyla birlikte etkisini yitirmekte ve durma noktasina gelmektedir. Verimlilikte görülen azalma ise kentlerde yığılan sermayenin giderek olgunlaşan teknoloji kullanması, beşeri sermayenin gelişememesi ve vasıfsız işgücü yoğun bir istihdam yapısına dönüşmesi ile açıklanmaktadır. Diğer bir bakış açısılla beşeri sermayenin ve teknolojik ilerlemenin anahtarı konumunda olan "bilgi"nin eksikliği halinde, işgücü ve sermaye faktörlerinin verimliliğinde önemli düzeyde azalmalar ortaya çıkmaktadır. Ayrıca, düşük gelirli ekonomilerin yurt dışından transfer ettikleri basit teknoloji kullanarak ürettikleri ucuz maliyetli ve emek yoğun ürünler ile düşük emek maliyeti avantajını da kullanarak, uluslararası piyasalarda rekabet üstünlüğü elde ettikleri de görülmektedir. Emek ve sermayenin, verimliliği düşük tarım sektöründen daha yüksek verimliliğe sahip imalat sanayi sektörüne kaymasıyla birlikte ülkenin üretkenlik düzeyi ve doğal olarak da gelir düzeyi yükselmektedir. Fakat bu ekonomilerin gelir düzeyi açısından orta gelir sınırı olarak kabul edilen seviyeye ulaşmaları ile birlikte, kırsal kesimdeki eksik istihdam azalmakta, ücretlerle birlikte uluslararası rekabet gücü de düşmektedir. Yeni teknolojileri kullanarak üretkenliğini artıramayan ülkeler ise tuzak sınır düzeyinin üzerine geçememektedir. Bununla birlikte, yüksek bilgi beceri gerektiren yenilikçi ürünler üreten ve emeğin yoğun kullanıldığı ürünlerde ucuz emek kullanan düşük gelirli ülkeler ile rekabet edemez duruma da gelmektedir (World Bank, 2013).

Orta gelir tuzağında olan ülkelerde büyüme hızı, emeğin ve sermayenin azalan getirisi nedeniyle yavaşlamakta, bu durum zamanla kararlı hale gelmekte ve böylece teknolojik ilerlemeye ayak uyduramayan ve eğitimin kalitesini arttıramayan ülkeler birbirine benzeyerek yakınsamaya başlamaktadır. Dünya Bankası'nın sınıflandırmasına göre yüksek orta gelir ve altında yer alan ülkelerin temel özelliği tam da budur: "eskimiş teknoloji ve vasıfsız emek kapasitesi” (Yeldan vd. 2012).

\section{1. Ülkeler Neden Orta Gelir Tuzağına Girer?}

Ülkelerin içinde bulunduğu kalkınma evresi, orta gelir tuzağının açıklanması açısından önem taşımaktadır. Ekonomiler orta gelir tuzağına yaklaşırken tarımdan sanayiye işgücü transferine dayanan hızlı ve kolay büyüme kaynakları zamanla etkisini yitirmekte, kullanılan teknoloji olgunlaşmakta ve eskimektedir. Aynı zamanda, sermaye karlılığını yitirirken vasıfsız işgücü ve doğal kaynaklara dayanan sermaye birikimi de yavaşlamaktadır. Ekonominin düşük teknolojili üretim yapma kapasitesine sahip olması ile özellikle imalat sanayinde emek yoğun üretimin hakim olması ise ülkeleri adeta orta gelir tuzağında hapsetmektedir (Taşçı ve Özsan, 2014). Yani, geçim ekonomisinden, düşük teknolojili imalat sanayi ekonomisine dönüşümle ortaya çıkan katma değer artışı, belirli bir seviyede sabitlenmekte 
ve kişi başına gelir tanımlanan sınırın üzerine çıkamamaktadır. Bu durumu yaşayan bir ülkede sermayenin ihtiyacı olan temel unsur beşeri sermaye ve teknolojiye yapılacak yatırımlar ile verimliliğin ve katma değerin arttırılmasıdır (Tho, 2013).Yani üretkenliğin, eğitim ve araştırma-geliştirme yatırımlarının iyileştirilmesi yoluyla arttırılması, orta gelir tuzağından çıkılmak için atılması gereken birincil adımdır.

Yeldan vd.'ye (2012) göre orta gelir tuzağ1 sorununa bölgesel açıdan yaklaşılması çözüm için önem taşımaktadır. Çünkü bölgelerin toplam faktör verimliliği birbirinden farklıdır ve üretim belli bölgelerde yoğunlaşmaktadır. Bir ülkede yaşayan hane halkının tüm bölgelerde farklı sayıda olması, işgücünün kalite ve verimlilik seviyelerindeki heterojen yapı, farklı gelir düzeyinde tüketici tercihlerinin değişmesi ve üretim kalıplarındaki çeşitlilik, eşit gelişmişlik olgusunun önüne geçmektedir (Taşçı ve Özsan, 2014). Bölgeler arasındaki ayrışmalar beraberinde politika çeşitliliğini getirmekte ve her bölgenin kendi sorununa göre politika uygulanmasının gerekliliği ortaya çıkmaktadır. Bunun yanında ayrışan her bir bölge için bölgenin yapısı ve dinamikleri göz önünde bulundurularak oluşturulan bölgesel politikaların yanında, ulusal ekonominin bütünlüğü de gözetilerek üretilecek politikaların kapsamlı, kendi içerisinde tutarlı ve bütünleşik olarak tasarlanması da önem arz etmektedir (Yeldan vd., 2013).

\subsection{Türkiye Orta Gelir Tuzağında (Mı?)}

Türkiye ekonomisi için orta gelir tuzağı sorunu incelendiğinde, uzun yıllardır sanayileşmiş ülkelere kıyasla oldukça yavaş seyreden sabit sermaye yatırımları,vasıfsız işgücü ve düşük teknoloji gibi göstergelere ek bir faktör olarak ortaya çımaktadır. Bununla birlikte Türkiye'de bölgesel gelişmişlik farklılıkları, ulusal ekonominin parçalanmış görünümü, göreli olarak yoksul bölgelerin ucuz işgücü ve hammadde ile daha üretken ve zengin bölgeleri beslemesine, bu yolla da bölgesel farklılaşmanın bir kısır döngü haline gelmesine yol açmaktadır.

Sermaye faktörünün aşırı yoğun kullanımı ve göreli olarak verimin düşüklüğü ampirik yazında genel kabul gören ve sık vurgulanan bir olgu olarak kendini göstermektedir. Toplam faktör üretkenliğinin büyümeye katkısı genel olarak sadece 1980-89 yılları arasında, görece kısa bir süre için, anlamlıdır. Ekonominin yeniden bir yapılanma içine girdiği, ticaretin ve faktör piyasalarının konsolide edildiği bu dönemi 1990'ların denetimsiz finansal serbestleşmesi ile gerçekleşen oynaklık ve belirsizlik ortamı izlemiştir. Türkiye'nin 2005 sonrası büyüme seyri ise göreli olarak çok yüksek dış açık ve ucuz ithalat olanağının sağladığı aşırı sermaye yoğun teknolojilere sürüklenmesi sonucunu doğurmuştur (Yeldan vd., 2012). Ayrıca, özellikle son dönemlerde istihdam yaratmayan büyüme olgusu ve aşırı sermaye yoğun üretim yapısı da sermaye ve emeğin kalitesini ön plana çıkarmaktadır. Ancak, 
durgunluğun başlıca sebebi olan sermaye stokunun yavaş büyümesinin aşırı sermaye yoğun büyümeden daha önemli bir unsur olduğu da gözden kaçırılmamalıdır. Bu yapıya olgunlaşmıs teknoloji kullanan sermaye yapısının büyümeye etkisinin zayıf kalması eklendiğinde orta gelir tuzağından çıkmanın nerede ise olanaksız hale geldiği bir durumla karşı karşıya olunduğu ortaya çıkmaktadır.

Tablo 2. Seçilmiş Göstergelerde Türkiye ve Gelişmiş Ülkeler Karşılaştırması

\begin{tabular}{lcc}
\hline & Türkiye & $\begin{array}{c}\text { Yüksek Gelirli } \\
\text { Ekonomiler }\end{array}$ \\
\hline Ar-Ge/Milli gelir & $\% 1$ 'in altında & $\% 1,5-\% 3,5$ \\
Ortalama örgün eğitim & 7,2 y1l & $11-12 \mathrm{yll}$ \\
Kadınların işgücüne katılım oranı & $\% 30$ & $\% 50+$ \\
Yurtiçi tasarruf/Milli gelir & $\% 14$ & $\% 17$ \\
İmalat sanayi içinde yüksek & $\% 2-3$ & $\% 10+$ \\
teknoloji sektörlerin payı & & \\
\hline
\end{tabular}

Kaynak: TÜIK, 2016; World Bank, 2013

Dünya Bankası'nın (2013) raporunda üst-orta gelirli ülkeler sınıfında yer alan Türkiye'nin neden yüksek gelirli ekonomiler düzeyinde olmadığını yansıtan başlıca göstergeler arasında şu faktörler yer almaktadır: Ar-ge harcamalarının milli gelir içindeki payı, ortalama örgün eğitim süresi, kadınların işgücüne katılım oranı, yurtiçi tasarrufların milli gelir içerisindeki payı ve imalat sanayi içindeki yüksek teknolojili sektörlerin payı. Ar-ge harcamalarının milli gelir içindeki payı Türkiye'de $\% 1$ 'in altında iken, gelişmiş yüksek gelirli ekonomilerde \%1,5-3,5 seviyelerindedir. Emeğin kalitesini etkileyen diğer bir önemli unsur olan ortalama örgün eğitim sürelerine bakıldığında Türkiye'nin oldukça geri durumda olduğu görülmektedir. Bu süre Türkiye'de yaklaşı 7 yll, yüksek gelirli ekonomilerde ise 11-12 yıldır. Buna ek olarak Türkiye'de kadınların işgücüne katılım oranı \%30 seviyelerinde iken gelişmiş ülkelerde \%50'nin üzerindedir. Yurtiçi tasarruf oranında da durum farklı değildir. Yüksek gelirli ekonomilerin tasarruflarının milli gelir içindeki pay1 $\% 17$, Türkiye de ise $\% 14$ 'tür. Türkiye'yi yüksek gelirli ekonomilerden ayıran bir diğer unsur da imalat sanayi içindeki yüksek teknolojili sektörlerin payıdır ve söz konusu bu pay Türkiye'de \%2-3 arasında gerçekleşirken, gelişmiş ekonomilerde \%10'un üzerindedir. Bu göstergeler Türkiye'nin önemli düzeyde teknoloji, eğitim ve tasarruf açığı olduğunu açıkça ortaya koymaktadır. Orta gelir tuzağı olarak kabul edilen sınırın üzerinde bir kişi başı gelirin elde edilebilmesi için sözü edilen göstergelerde zaman kaybetmeden iyileştirmelerin yapılması zorunlu hale gelmektedir.

Türkiye'nin1980 yılında dolar bazında kişi başına GSYH'si, ABD'nin kişi başına GSYH'sinin \%12'si civarındadır. Bu durum 80'li yılların başlarında Türkiye'nin orta gelir sınırının da altında gelire sahip olduğunu ifade 
etmektedir. Takip eden yıllarda \%7'ye düşüp, sonrasında $\% 11-13$ arasında seyreden bu oran 2001 ve 2002 ylllarında tekrar en düşük değerlerini almıştır. 2001 krizi ve TL'nin değer kaybı bu duruma yol açmıştır.Sonraki yıllarda TL'nin değer kazanmasına ve ülkenin göreli olarak büyümesine de bağlı olarak yukar1 yönlü hareketlenmiş ve $\% 20$ civarına yerleşmiştir. Sadece bu görünüm bile Türkiye'nin orta gelir tuzağında olduğuna işaret etmektedir.

\section{Literatür}

Eichengreen vd.(2013) orta gelir tuzağını gelişmekte olan ülkelerin büyüme hızlarının yavaşlaması olarak tanımlamış ve yüksek değerlere sahipken sonrasında hızı düssen büyümenin de etkisiyle sabit bir gelir düzeyine doğru evrilen ülkeleri bu tuzağın tam ortasında kabul etmiştir. Araştırmacılar, büyümenin durgunlaşması kabulünü üç koşula bağlamıştır: Birinci koşul, satın alma gücü paritesine göre ve 2005 fiyatları ile kişi başı gelirin büyüme oranının en az \%3,5 olmasıdır. İkinci koşul, gösterge kişi başı gelirde negatif yönde bir seyir olmalı ve bunun oranı da en az $\% 2$ şeklinde gerçekleşmelidir. Büyümenin durgunlaştığını ve hatta ekonominin küçüldüğünü ifade eden üçüncü koşul ise kişi başı gelirin 10.000 dolar seviyelerinde olmasıdır.

Aiyar vd.(2013) orta gelir tuzağının hızlı büyüme sürecinin önce durgunlaşan sonrasında ise düşen bir büyüme süreci ile ortaya çıktı̆̆ını ifade etmiştir. Bu nedenle söz konusu durumu gelişmiş ülke seviyelerine ulaşmadaki başarısızlık olarak tanımlamıştır. Büyümede yaşanan sert düşüşe neden olarak verimlilikteki azalmayı gösterirken, verimlilikte azalmayı tespit için kurumların, demografik yapının, altyapının, makroekonomik politikaların, ekonominin genel ve ticari yapısının da ele alınmasının gerekliliği ortaya koymuştur. Çalışmanın bir diğer önemli bulgusu da özellikle ticaretteki bölgesel bütünleşmenin büyümenin durgunlaşmasının önüne geçebileceğini göstermesidir.

Literatürde orta gelir tuzağı ile ilgili bir başka bakış açısı ise ülkelerin gelişmişlik ve kişi başı gelir düzeylerinin birbirlerine yakınsamasına ilişkindir. $\mathrm{Bu}$ yaklaşımda ülkelerin gelirleri, yüksek gelirli ekonomilere göreli olarak ele alınır. Orta gelirli ekonomiler genellikle ABD kişi başı gelir düzeyi ile karşılaştırarak tespit edilir ve benzer sosyoekonomik özellikte olan ülkelerin gelirleri de zamanla birbirine yakınsamaya başlar. Ayrıca, kişi başı geliri ABD gelirinin \%20-50 arasında olan ülkeler orta gelir tuzağında ya da potansiyelinde olarak sınıflandırılır. Bu oran \%55'in üstünde ise üst gelirli, \%20'nin altında ise düşük gelirli ekonomi olarak adlandırılır (Woo, 2012).

Tho (2013) ülkeleri ve ülke içindeki bölgeleri kalkınma seviyesi bakımından birbirinden ayıran unsurların kaynak farklılı̆ından ortaya çıktığını belirtmiştir. Beşeri sermaye ve teknoloji olarak iki temele oturttuğu ve orta gelir tuzağına karş1 iyileştirilmesi gerekliliğini vurguladığı bu kaynaklar, "araştırmageliştirme" ve "eğitim”'dir. Çalışmada vasıflı emek ve sermayenin, gelişmede 
ve bölgelerarası farklılaşmada avantaj yarattığını tespit edilmiş ve bunun sürekli hale getirilmesinin ancak inovatif ürünlerle mümkün olabileceğine değinilmiştir (Tho, 2013).

OECD'nin (2013) Çin ekonomisinin orta gelir tuzağında olup olmadığına ilişskin hazırlamış olduğu raporunda orta gelirli ve yüksek gelirli ülkeleri birbirinden ayıran gelir seviyesi olarak 2011 fiyatlarıla 12.500\$ belirlenmiştir. Bölgesel farklılıklar, ekonomi politikalarının kalitesi, teknoloji ve beşeri sermayenin içerildiği kaynaklar arasında bağlantılar olduğuna değinilen çalışmada, yapısal reformların da söz konusu farklılaşmada önemli rol oynadığına dikkat çekilmiştir. Rapora göre, özellikle finans ve emek piyasaları ile tarım arazilerinin mülkiyeti ile ilgili reformlar öncelikli olarak ele alınmalıdır. Ayrıca çevresel sürdürülebilirlik (ki bunun içerisine gıda güvenliği, sosyal güvenlik ağları, sağlık ile kentleşme dahil edilebilir) istikrarlı ve sağlıklı katma değer yaratan büyümenin olmazsa olmazları arasında belirtilmiştir.

Paus(2013), Latin Amerika ülkelerinde yaşanan sosyoekonomik farklılıkların temelini oluşturan unsurları ortaya çıkarmayı amaçladığı çalışmasında, emek verimliliğindeki farklıllğın bölgesel gelişmişlik düzeyini değiştiren en önemli unsur olduğunu ortaya koymuştur. Emeğin verimini ise eğitimin öne çıtığı sosyal yetenekler ile teknolojinin öne çıttı̆ı yerel firmaların yeteneklerine bağlamıştır. Ayrıca bölgesel ve yerel üretim koordinasyon eksiklikleri, şeffaflığın sağlanamamış olması, mali kaynak dağılımındaki adaletsizlikler ile teknik ve profesyonel yetenek zafiyetleri yerel ve küresel ekonomileri birbirinden ayırmaktadır.

Yiping vd. (2013), kalkınma ve orta gelir tuzağıyla mücadelenin anahtarının endüstriyel gelişme olduğunu belirtmişlerdir. Ancak yenilikçi teknolojilerle desteklendiğinde mümkün olabileceğini de eklemişlerdir. Yenilikçi teknolojilere odaklanma, çevre dostu yeşil büyüme ve yapısal reformların itici gücünün öne çıkarılması gelişmekte olan ülkeleri bir üst sınıfına çıkarmada önem arz etmektedir.

Ülkelerin gelişmişlik düzeyi bakımından birbirine yakınsaması ve hatta avantajlı konuma geçmesini sağlayacak unsurun, emeğin eğitimle vasfinın arttırllması yoluyla sağlanabileceğini vurgulayan Lee (2013), yaratıcilı̆̆ın önemine dikkat çekmiştir. Ülkelerin doğrudan yabancı yatırım olarak imalat sanayi yatırımlarını çekmesiyle gelişmeye başladığını belirtmiş ve bu ekonomilerin basit üretim ölçeklerinde kümelenme aşamasından sonra teknoloji çeken bir konum aldıklarını ifade etmiştir. Yaratıcılık sayesinde elde edilen yüksek kaliteli mal üretimi ekonomilere, Japonya, ABD ve Avrupa Birliği'nin birçok ülkesinde olduğu gibi, yenilikçi ve küresel pazarda lider olma özelliği kazandırmaktadır.

Tuncel (2014), Lee'nin (2013) çalışmasını destekler nitelikte, Güney Kore ve Tayvan ekonomilerinin orta gelir tuzağından çıkmalarındaki itici gücün 
devletin aktif sanayi ve inovasyon politikaları olduğuna değinmiştir. Tuzağa yakalanmış ekonomiler,teknolojiyi ar-ge faaliyetleri ile içselleştirdiklerinde ve devletin kaynak tahsisinde yönlendirici rol üstlenmesi ile önemli gelişmeler elde edebileceklerini vurgulamıştır.

Gürsel ve Soybilen (2013) e göre sermaye stoku büyüdükçe sermayenin ek getirisinin giderek azalacak, böylece kişi başına gelir artışı giderek yavaşlayacak ve ardından durağanlaşacaktır. Buna karşı koyabilmek için teknoloji düzeyi ile çalışanların bilgi ve beceri düzeyinin (insan sermayesinin) yükseltilmesi ve ekonomik işleyişin etkinliğinin sürekli hale getirilmesi gerekmektedir. Atılması gereken başlıca adım ise yatırımların teknolojik ilerleme içermesi, çalışanların eğitim ve beceri düzeylerinin artması ve ekonominin çarklarının daha etkin şekilde dönmesidir. Böylece emek verimliliği arttırılabilecektir.

Kurtoğlu (2014), orta gelir tuzağından çıkmak için bilginin girdi olarak yer aldığ1 üretim fonksiyonu çerçevesinde üretim faktörlerini ele almıştır. Çalışmanın sonuçlarına göre gelişmekte olan ekonomilerde orta gelir tuzağı seviyesini aşmak için bilgi yoğun üretim faaliyetlerinin payının artırılması ve verimlilik artışı sağlayacak yenilik ekonomisi yaratılması gereklidir. Çalışmanın en önemli bulgularından birisi önceki dönem teknolojiyi içeren fiziki sermaye faktörünün sağladığı verimlilik artışının, bilgi faktörünün doğrudan sağladığ1 verimlilikten daha düşük düzeyde gerçekleştiğidir. Bir diğer ifade ile bilgiyi temel üretim faktörü olarak alan yaklaşımla bilginin ar-ge ve yenilik sürecine dahil edilmesi ile daha yüksek verimlilik ve katma değer sağlanmaktadır.

Türkiye'deki kentlerin ve bölgelerin gelişmişlik düzeylerinden hareketle farklı gelir seviyelerine sahip olduğuna değinen Çavuş (2014), sosyoekonomik farklılıkların bazı bölgelerin üst gelir grubunda olmasına katkı sağlarken, bazı bölgelerin ise belirli bir gelir düzeyinde takıllp kalmasına neden olduğunu vurgulamıştır. Çalışmada, bölgeler üretim yapısını belirleyen sektörlerdeki teknoloji yapısına göre de ayrıştırılarak kent ve bölgeler beş gelişmişlik düzeyi temelinde incelemiştir.

Yeldan vd. (2012) çalışması, Türkiye'de orta gelir tuzağı ile ilgili ilk kapsamlı ampirik araştırmadır. Bu çalışmada, Türkiye'de orta gelir tuzağını hazırlayan dinamikler bölge bazında tartışılmakta ve bir hesaplanabilir genel denge modeli kullanılarak bölge bazında gelişme stratejileri geliştirilmektedir. Çalışmanın ayırt edici bir özelliği bölgeleri orta gelir tuzağına girme riskine göre derecelendirmiş olmasıdır.

$\mathrm{Bu}$ çalışmanın çıkış noktası bölgesel farklılıklardır. Orta gelir tuzağına bölgesel farklılaşma fikrinden yola çıkarak yaklaşım Yeldan vd. (2012) ile benzeşmektedir. Ancak kullanılan yöntem Yeldan vd. (2012)'den farklıdır. Seçilen ekonometrik yöntem bölgesel analiz yapmaya elverişlidir. 


\section{Metodoloji}

\subsection{Veri Seti}

Ampirik analizde karşılaşılan en önemli kısıt incelenen dönemde kesintisiz verinin olmamasıdır. Ele alınan veri seti 2004-2011 yıllarını kapsarken, bu durumun temel nedeni, çalışmada bağımlı değişken olarak kullanılan ve TÜIKK tarafindan açıklanan kişi başı katma değer serisinin 2011 yllı sonrasında yayımlanmamasıdır. Zaman boyutu 8 yıl olan veri seti 26 tane Düzey 2 Bölgesi bazında düzenlenmiş, böylece toplam gözlem sayısı 208'e ulaşmıştır. Bölgesel verim farkından hareket ederek ve kişi başına katma değerin farklılaşacağ öngörüsü ile hazırlanan bu ampirik çalışmada bağımlı değişken, bölge bazında kişi başına gayri safi katma değerdir. Bağımsız değişkenler ise dört ana grupta toplanmaktadır: ar-ge, altyapı, işgücü piyasası ve eğitim. Bu ilişkiyi yansıtan teorik modelin kapalı formu denklem 1'de verilmektedir ve değişkenler Tablo 3’te gösterilmektedir.

$$
\text { KBGSKD = f(isgucud.; egitimd.; ar-ged. ; altyapid.) }
$$

İşücü piyasasıyla ilgili değişkenler için; 19- ve 55+ yaş gruplarının işgücü içindeki paylarının artmasının bağımlı değişken üzerinde negatif etki yaratması beklenirken, yüksek öğretim mezunlarının işgücü içindeki ve 50 üzeri istihdam yaratan işyerlerinin toplam içindeki paylarının artmasının ise bağımlı değişken üzerinde pozitif etki yaratması beklenmektedir. Eğitime ilişkin Tablo 3'te gösterilen üç değişkenden son ikisindeki yükselmenin kişi başına gayri safi katma değeri yükseltmesi beklenirken, orta öğretimde öğretmen başına öğrenci sayısının artmasının ise tersi etkiyi yaratması beklenmektedir. Ar-ge'ye ilişkin kullanılan tek gösterge tescil alan patent başvurularının oranıdır ve bu değişken için beklenen katsayı pozitiftir. Son değişken grubu altyapıya ilişkindir ve burada kamu yatırımlarının istihdam yaratma potansiyeli ve birim alana düşen karayolu uzunluğu içerilmiştir. Her iki değişkenin bağımlı değissken üzerinde pozitif etki yaratması beklenmektedir.

\section{Tablo 3. Analizde Kullanılan Bağımlı ve Bağımsız Değişkenler}

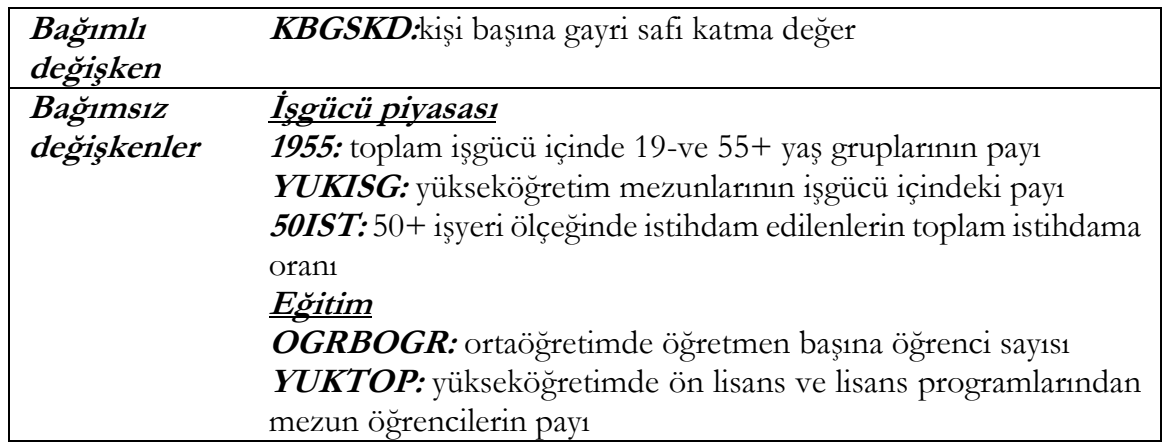




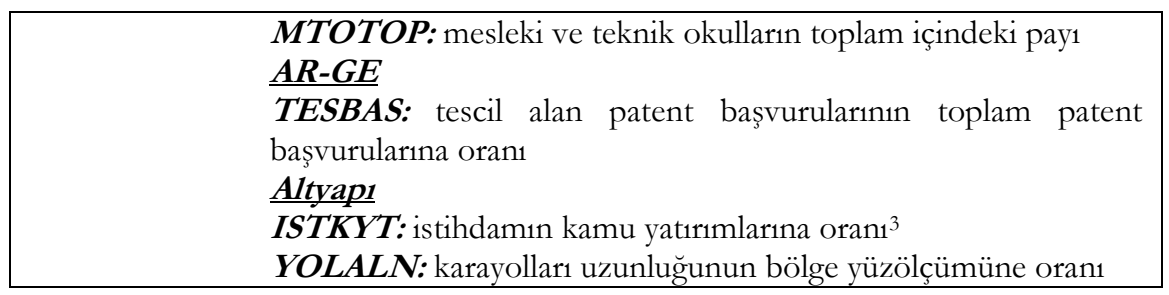

\subsection{Ekonometrik Analiz}

Çalışmanın çıkış noktası, bölgelerin birbirlerine olan uzaklıkları ve/veya bölgelerarası komşuluk ilişkilerinin (mekânsal özelliklerin) bireylerin gelir seviyeleri üzerinde etkili olabileceği öngörüsüdür. Bölgeler arası heterojen yapının ortaya çıkarılması ve buradan hareketle orta gelir tuzağında yer alan Türkiye'nin, bölgesel farklılı̆̆ının yansıtılması hedeflenmektedir. Ekonometrik analizin amac1, Türkiye'de Düzey 2 bölgeleri (26 adet) arasındaki kişi başına düşen gayrisafi katma değerdeki (KBGSKD) farklılığın sosyal sermaye, işgücü piyasası, ar-ge ve altyapıya yönelik değişkenler tarafından ne kadar açıklanabildiğini ortaya koyabilmektir.

Ekonometrik tahminlerde iki temel yöntem kullanılmıştır. Birinci yöntem olarak mekânsal özelliklerin bölgelerdeki KBGSKD değişkenliğini ne kadar açıkladığını belirleyebilmek için "coğrafi olarak ağırlıklandırılmış regresyon" (CAR) yöntemi seçilmiştir. CAR yatay kesit, yani bu çalışmada Düzey 2 bölgeleri, bazında bilgi üretirken tek bir yıl için yapıldı̆̆ından açıklayıc1 değişkenlerin trend etkisini vermemektedir. Öte yandan bölgesel heterojenite ve uzaklık ilişkilerinin yarattığ dişsallık etkilerini tahmin edilmiş değişken katsayılarına yansıttığından standart yatay kesit tahminlerden ve yatay kesit bazında sabit etki panel modellerden daha güvenilir tahminler vermektedir (Brunsdon, Fotheringham, ve Charlton, 1996; Fotheringham, Brunsdon ve Charlton, 2002). Yine de bir mukayese yapabilmek amaciyla CAR tahminin dönem başı ve sonunda iki kez yapılmıştır. Bu noktada, CAR'da kullanılan yatay kesit sayısının serbestlik derecesini düşürerek güven aralığını genişletip genişletmeyeceği sorusu akla gelebilir. Tahminler bu olası eleştiri dikkate alınarak yapılmakla birlikte (en fazla 3 bağımsız değişken modele koyulmuştur) özellikle CAR'dan kaynaklanan bir bağımsız değişken sayısı artış1 yoktur. CAR yatay kesitler arasındaki mesafeleri tahmin katsayılarını hesaplarken kullanmakta ve bağımsız değişken sayısını arttırmamaktadır.

Ekonometrik tahminlerde kullanilan ikinci yöntem sabit etki panel tahmin yöntemidir. Bu yöntem bölge ve yıllara göre otonom KBGSKD'de meydana gelen değişimi görebilmek için uygulanmıştır. Aynı zamanda açıklayıcı

${ }^{3}$ TÜİK toplam veya özel sektör bölgesel sabit sermaye yatırımlarını vermediğinden bu gösterge kamu yatırımları ile sınırlı tutulmuştur. 
değişkenlerin zaman içinde değişen trendlerinin etkileri de tahmin edilmiş katsayılar üzerinde görülebilecektir.Panel veri analizinin sabit etki tahmini için uygun olup olmadığı Hausman testi ile sınanmıştır. Bir başka ifade ile kullanılan farklı ekonometrik yöntemler ile aşağıdaki soruların cevapları aranmaktadir:

- Dürey 2 Bölgelerinnde kişi başına dïssen gayrisafi katma değerdeki değz̧simi açıklamak için kullamilan model, hem 2004 hem de 2011 yullarnda aym/yakun açklama gücüne sabip midir?

- Türkiye'de kişi başına düsen gayrisafi katma değerdeki farkllhl̆ğ açıklamak için istatistiki olarak anlaml bulunan değģskenler, Düzey 2 Bölgeleri arasinda değisen etkiye sahip midir?

- Dürey 2 Bölgeleri arasinda değgisen etkiye sabip bulunan değisskenler, 2004 ve 2011 yallarnda ayn midr?

- Düzey 2 Bölgeleri arasinda otonom gayrisafi katma değer farklille göstermekte midir?

- Türkiye'de kişi bassı otonom gayrisafi katma değer, 2004-2011 arasindaki 8 ynllke dönem içinde yul bąunda ne kadar farklhlke göstermektedir?

\subsubsection{Mekansal Analiz}

Coğrafi Olarak Ağırlıklandırılmış Regresyon (CAR) yöntemi kullanarak 2004 ve 2011 yll için gerçekleştirilen ekonometrik tahmin sonuçları Tablo 4 ve Tablo 5 'te gösterilmektedir' . Tablolar hem global hem de lokal modellerin tahminini içermekte, lokal model bölgesel sonuçları ise Ekler'de verilmektedir. Global model bağımsız değişkenlerin ülke ortalamasını temsil eden katsayı etkilerini yansıtırken, lokal model aynı bağımsız değişkenlerin yatay kesit bazında katsayı etkilerini vermektedir ${ }^{5}$. Global model sonuçları incelendiğinde her iki yıl için aynı değişkenlerin (OGRBOGR, MTOTOP, 50IST) istatistiki olarak \%1 düzeyinde anlamlı bulunması bir tutarlilık olarak gözlenmektedir. Modellerin toplam aç1klama gücü arasında bir farkllılk söz konusudur (düzeltilmiş $\mathrm{R}^{2}$ değerleri). Her iki yllda da istatistiki olarak anlamlı çıkan üç değişkenin tahmin edilmiş katsayı işareti beklentiler ile uyumludur. Eğitimin bireyin ve dolayısıyla da emeğin niteliğini arttıracağ eklenen orta öğretimde öğretmen başına öğrenci sayısı (OGRBOGR) artışının eğitimin kalitesini ve buna bağlı olarak kişi başına gayri safi katma değeri

\footnotetext{
${ }^{4}$ Tahminler işgücü piyasası, eğitim ve altyapı ana grupları içinden toplam dokuz değişkenle gerçekleştirilmiş, istatistik olarak anlamsız bulunan değişkenlerin çıkarılmasından sonra tekrar tahmin edilen ve sadece anlamlı değişkenleri içeren model sonuçları tablolarda verilmiştir.

${ }^{5}$ Modelde bağımlı değişken ile işgücü piyasasına ilişkin değişkenler arasında bir endojenite probleminin varlığı düşünülebilir. Burada amaç nedensellikten çok bir ilişkinin varlığını göstermektir. $\mathrm{Bu}$ sebeple endojenite probleminin olmayacağı varsayılmıştır. Ayrıca, bu değişkenlerin oluşturulma yöntemi (değişkenlerin tanımı) bağımlı değişkende otomatik bir artmayı doğurmamaktadır, bu sebeple de anılan problemin üzerinde durulmamıştır.
} 
düşürmesi beklenmektedir. Bulgulara göre 2004 yllında bu değişkende meydana gelen 1 birimlik artış bağımlı değişkeni 0,19 birim azaltmakta iken, 2011 yllinda bu etki 0,14 birimdir. Toplam eğitim sistemi içerisinde meslek ve teknik okulların payını temsil eden değişkende (MTOTOP) gerçekleşen 1 birimlik iyileşme ise kişi başı gayri safi katma değeri 2004 yllında 0,08 birim artıırken, 2011 yılında 0,09 birim artırmaktadır. Türkiye'de eksikliği ifade edilen ve "ara sinıf" olarak anılan meslek ve teknik okulları için bulunan pozitif katsayı oldukça tutarlı bir sonuçtur. İşyeri ölçeği büyümesinin, iş bölümü ve uzmanlaşma ile katma değere olumlu yansıyacağı düşüncesi ile analizde yer verilen $50+$ işyeri ölçeğinde istihdam edilenlerin toplam istihdamdaki payının (50IST) 1 birimlik artısı ise 2004 yılında bağımlı değişkeni 0,21 birim artırmaktadır ki bu da beklentilerle uyumlu bir sonuçtur. Aynı etki 2011 yllında 0,21 birimdir. Her iki yılda da öğretmen başına öğrenci sayısının artması kişi başı gayri safi katma değere olumsuz olarak yansımakta iken, toplam içinde meslek ve teknik okullarının payı ile 50+ işyeri ölçeğinde istihdam edilenlerin toplam istihdam içindeki payının büyümesi katma değeri artırıcı yönde etki yapmaktadır. Bu sonuçlar eğitime ve işgücüne yönelik yapılacak iyileştirici politikaların, katma değer üzerindeki gerçekleşen ve potansiyel etkisini göstermesi bakımından önemlidir.

Global model sonuçları 2004 y1lında 50IST in, 2011 yllında ise OGRBOGR, MTOTOP ve 50IST değişkenlerinin etkilerinin Düzey 2 Bölgeleri bazında değişkenlik gösterdiğine işaret etmekte ve bu değişsenlerin lokal olarak tahmin edilmesi gerektiğini göstermektedir7. Buradan hareketle modeller global ve lokal değişkenler ayrımı yapılarak tekrar tahmin edilmiştir. Bu şekilde modellerin toplam açıklama gücünün 2004 ve 2011 yıllarında sirasıyla 0,92 ve 0,90 ’a çıktığ görülmektedir. Analiz sonuçlarına göre, lokal modelin global modelden üstünlügünü gösteren bir diğer gösterge varyans analiz sonuçlarıdır. Kalıntı (artık) kareler toplamı her iki yılda da CAR analizi ve lokal tahmin sonucu global modele nazaran azalmaktadir.

Tablo 4. 2004 Yılı Coğrafi Olarak Ağırlıklandırılmış Regresyon Tahmin Sonuçlari ${ }^{\#}$

\begin{tabular}{|c|c|c|}
\hline \multicolumn{3}{|l|}{ Y11: 2004} \\
\hline \multirow{2}{*}{\multicolumn{2}{|c|}{$\begin{array}{l}\text { Gözlem: } 26 \\
\text { Bă̆ımlı değişken: lnKBGSKD }\end{array}$}} & CAR ANOVA \\
\hline & & Tablosu \\
\hline Global Model Tahmin Sonuçları & $\begin{array}{l}\text { Lokal Model Tahmin } \\
\text { Sonuçları (CAR) }\end{array}$ & Kareler toplamı \\
\hline $\begin{array}{l}\text { Kalıntı kareler toplamı: } \\
0,51\end{array}$ & 0,21 & Global kalıntı 0,51 \\
\hline AICc: & $-20,93$ & $\begin{array}{ll}\text { CAR etkisi } & 0,31\end{array}$ \\
\hline 0,89 & 0,95 & CAR kalıntısı 0,20 \\
\hline Düz. R²: & 0,92 & \\
\hline
\end{tabular}

${ }^{6} \mathrm{Ne}$ lise ne de üniversite mezunu.

${ }^{7}$ Eğer DIFF Kriteri $<2$ ise, değişken,lokal olarak değişen etki yaratabilmektedir. 
Türkiye'de Bölgesel Farklılaşmadan Orta Gelir Tuzağına Çıkarımlar

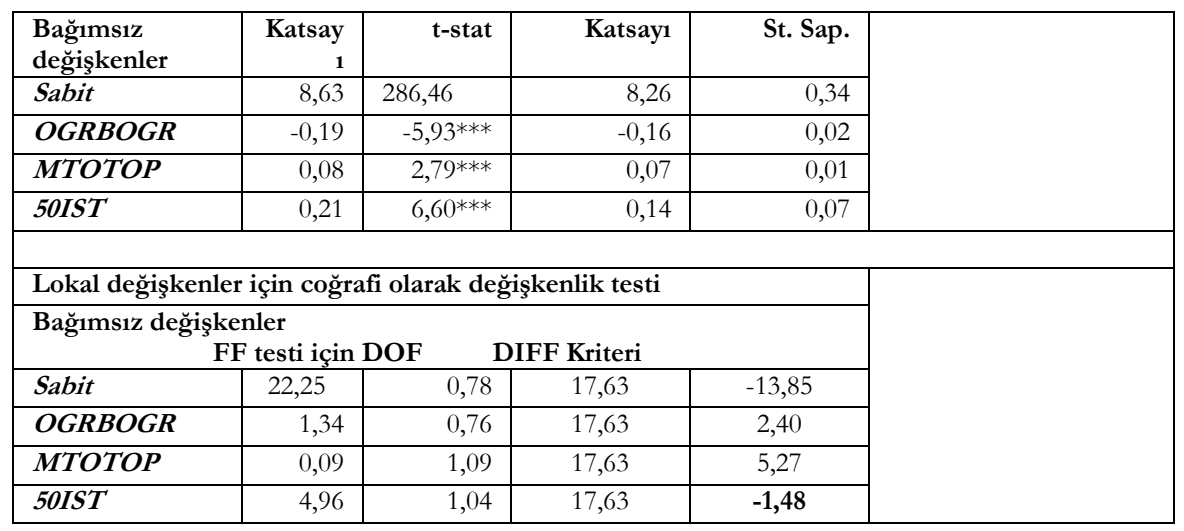

\#: Lokal katsayılar Ek’tedir. ***: \%1 istatistiki anlamlılık düzeyi.

Tablo 5. 2011 Yılı Coğrafi Olarak Ağırlıklandırılmış Regresyon Tahmin Sonuçlari ${ }^{\#}$

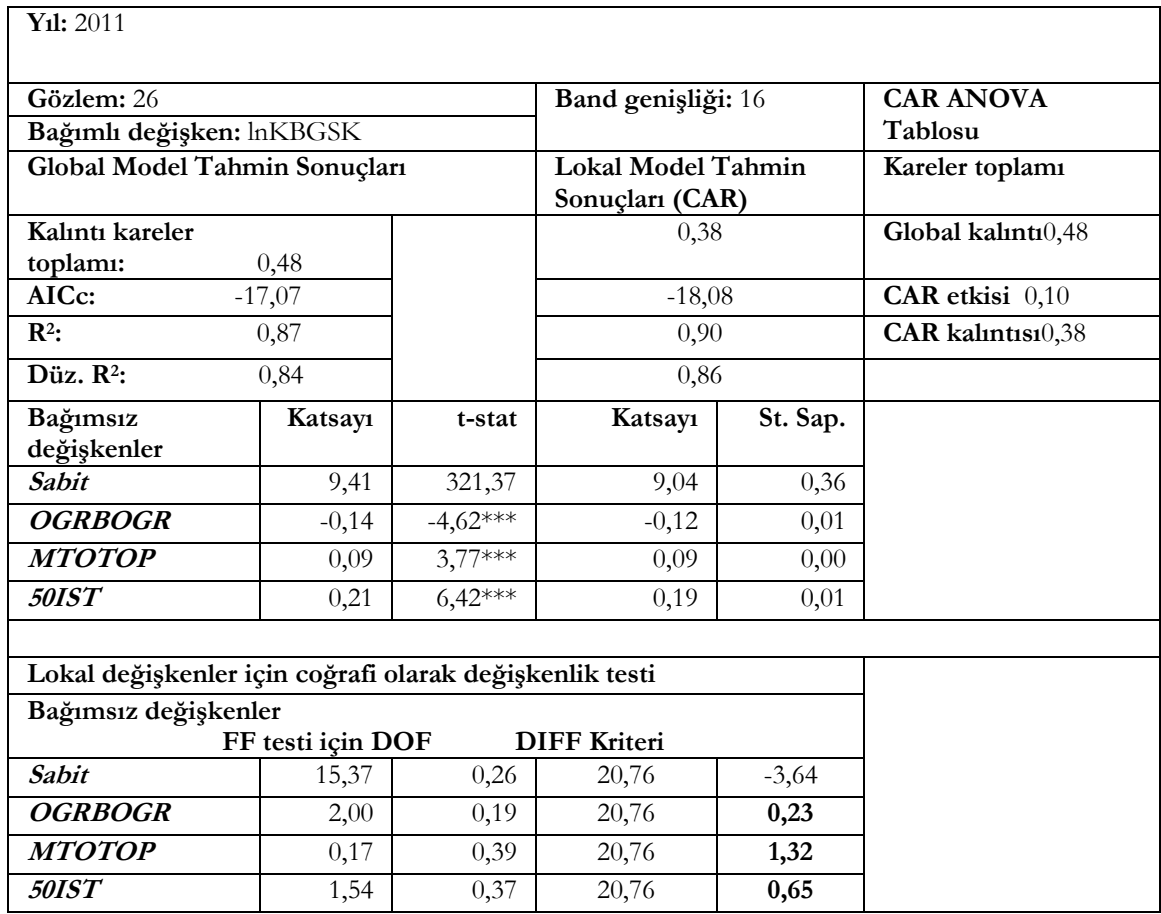

\#: Lokal katsayılar Ek’tedir. ***: \%1 istatistiki anlamlılık düzeyi.

Anılan değişkenlerin 2004 y1l lokal etkileri Tablo E1'de verilmektedir. Burada 50IST değişkeninin en düşük katsayı olarak 0,03 değerini aldı̆̆1 (TRC3 Bölgesi), en yüksek katsay1 değerini ise 0,21 olarak aldığ1 (TR82 Bölgesi) gözlenmektedir. Benzer şekilde model 0,83 düzeltilmiş $\mathrm{R}^{2}$ ile en düşük 
açılama gücünü TR41 Bölgesi’nde gösterirken, 0,94 düzeltilmiş $\mathrm{R}^{2}$ ile en yüksek açıklama gücünü TR82, TR83 ve TR90 Bölgeleri'nde vermektedir. Model, 2011 yllında 0,87 düzeltilmiş $\mathrm{R}^{2}$ ile en düşük açılama gücünü TR61, TR33, TRB1, TRC1 ve TRC2 Bölgeleri'nde göstermiştir. Buna karşın 0,89 düzeltilmiş $\mathrm{R}^{2}$ ile en yüksek açıklama gücünü ise TR21, TR22, TR32, TR62, TR71 ve TR82 Bölgeleri'nde vermektedir.

2004 yllına ilişkin sonuçlar ayrıntılı analiz edildiğinde " $50+$ işyeri ölçeğinde istihdam edilenlerin toplam istihdamdaki payı" değişkeninin kişi başı gayrisafi katma değeri arttırmak amacıyla hangi bölgelerde daha etkili olabileceğine dair işaretler verdiği görülmektedir. Katsayısı bölgelere göre 0,03-0,21 aralı̆ıında yer alan bu değişkenin kişi başı gayri safi katma değeri en az etkilediği bölge olarak TRC3 bölgesi öne çıkmaktadır. Bunun gibi TRB2, TRB1 ve TRA1 Bölgelerinde de 50IST değişkeninin nispeten düşük etki yarattığ1 gözlenmektedir. Buna karşın bu değişkenin en fazla etkili olduğu bölgeler ülkenin batısında yer almakta ve sanayi bölgelerinde yoğunlaşmaktadır. Bunlar TR21, TR22, TR31, TR32, TR51, TR52, TR10, TR42, TR62 ile TR41'dir. Bu bölgelerde 50IST değişkeninde meydana gelen 1 birim artış bağımlı değişkeni yaklaşık 0,20 birim artırmaktadır. Ayrıca bağımlı değişkeni etkilemesi bakımından göreli olarak daha güçlü olan bu bölgelerin modeli açıklama gücü de yaklaşık 0,90 düzeylerindedir.

2011 yllına ait lokal tahmin sonuçları değerlendirildiğinde ise MTOTOP değişkeninin bölgelerarası dikkate değer bir değişme yaratmadığı göze çarpmaktadır. OGRBOGR ve 5OIST değişkenlerindeki bir değişme, sırasıyla $0,12-0,14$ ve 0,19-0,21 aralıklarında farklılık yaratmaktadır. Düzeltilmiş $\mathrm{R}^{2}$ ise 0,87 ile 0,89 arasında yer almaktadır. Değişkenlerin 2011 yll bölgeler arası etki değişimi ve modelin açıklama gücündeki değişim 2004 yılına göre daha dar bir aralıkta gerçekleşmektedir. 2011 yll için tüm bölgelerde orta öğretimde öğretmen başına öğrenci sayısı (OGRBOGR) arttıkça, kişi başı gayrı safi katma değer azalma göstermektedir. Bu ters etkinin en fazla olduğu bölgelerin başında, lokal modelde açılama gücü de (düz. R²) nispeten daha yüksek olan TR21, TR22 ve TR32 gelmektedir. Bu bölgelerde OGRBOGR değisskeninde meydana gelen 1 birimlik artış bağımlı değişkeni -0,14 birim azaltmaktadır. $\mathrm{Bu}$ azaltıcı etkinin göreli daha düşük olduğu bölgelerin başında ise TR63, TR83, TRA2, TRB2 ve TRC3 gelmektedir. İşyeri ölçeğinde 50+ kişi istihdam edilenlerin toplam istihdamdaki payı değişkeninde meydana gelen 1 birimlik artış durumunda ise TRA2, TRB2 ve TRC3 bölgelerindeki kişi başı gayri safi katma değeri 0,21 birim artırmaktadır. Buna karşın TR62 ile TR71 bölgelerindeki artış daha düşük olurken, etki katsayıları 0,19 olarak tespit edilmiştir. 


\subsubsection{Panel Analiz}

Otonom kişi başına gayrisafi katma değerin Düzey 2 Bölgeleri arasında ve 2004-2011 döneminde yll bazında farklılık gösterip göstermediğini inceleyebilmek için panel ekonometrik modeller tahmin edilmiştir. Yapılan Hausman testi tesadüfi etkilerden ziyade, sabit etkili panel modeli destekler yönde bulgular vermiştir. ${ }^{8}$ Sabit etki modeli ile öncelikle 3 ana gruptan 9 değişkenle tahminler yapılmış, istatistiki olarak anlamlı çıkan 8 değişken OGRBOGR, YUKTOP, MTOTOP, YUKISG, 50IST, TESBAS, ISTKYT, YOLALN ile analize devam edilmiştir (Tablo 6). Modelin açıklama gücü 0,87 düzeyinde tespit edilmiştir. Kamu yatırımlarının istihdam yaratma potansiyelini temsil eden ISTKYT dışındaki tüm değişkenlerde beklenen yönde katsayı işaretleri elde edilebilmiştir. Bağımlı değişken kişi başı gayri safi katma değer (KBGSKD) iken, örneğin orta öğretimde öğretmen başına öğrenci sayısındaki (OGRBOGR) 1 birimlik artış, kişi başı gayri safi katma değeri 2.432 birim azaltmaktadır. Bağımlı değişken üzerinde en fazla etkiye ve katsayı bakımından en yüksek değere sahip değişkenlerin başında YUKISG gelmektedir. Toplam işgücü içinde yüksek öğretim mezunlarının payının 1 birim artması, KBGSKD'yi 5.807 birime yakın düzeyde artırmaktadır. Bu sonuçlar özellikle birey ve işgücü eğitimini temsil eden bu iki değişkenin katma değer üzerindeki etkisini göstermesi açısından önemlidir. Katma değer üzerinde önemli etkiye sahip bir diğer değişken 50IST tir ve 50'den fazla bireyin istihdam edildiği işyerlerinin payının 1 birimlik artması kişi başı gayri safi katma değer üzerinde 4.700 birime yakın olumlu etki yapmaktadır. Modelde karayolu yoğunluğunu temsil eden YOLALN değişkeninin katsayıs1 da beklenen yönde elde edilmiş ve karayolu yoğunluğunda oluşan 1 birimlik artışın bağımlı değişkeni 1.095 birim yükselttiği görülmüştür. Kişi başı gayri safi katma değeri artırma yönünde etkiye sahip diğer değişkenler ise tescil alan patent başvurularının oranı (TESBAS), toplam içinde yükseköğretimde ön lisans ve lisans düzeyinde mezun öğrenci payı (YUKTOP) ile toplam içinde mesleki ve teknik okulların payıdır (MTOTOP). Bu değişkenlerde meydana gelen bir iyileştirme bağımlı değişkeni olumlu yönde etkilemektedir.

Panel analizde beklentiler ile uyumlu sonuç vermeyen tek değişken kamu yatırımlarının istihdam yaratma potansiyelini temsil eden ISTKYT'dir. Bu

${ }^{8}$ Yapılan HausmanTesti'ne göre olasılık $0.0000<0.050$ olduğu için; $\mathrm{H}_{0}$ hipotezi reddedilir, yani rassal etki yoktur.

\begin{tabular}{llll}
\hline \hline Test Özeti & Ki-kare ist. & \multicolumn{2}{c}{ Ki-kare } \\
& & s.d. & Olasillk \\
\hline \hline Rassal yatay kesit & 69.082567 & 8 & 0.0000 \\
\hline \hline
\end{tabular}


değişken ile kişi başı gayri safi katma değer arasında aynı yönlü ilişkinin olması beklenirken, sonuç tersi yönde gerçekleşmiştir. Aslında kamu yatırımlarının istihdam yaratma potansiyelinin yükselmesinin KBGSKD'de artış yaratması beklenir ancak yapılan kamu yatırımları başına istihdam arttıkça, KBGSKD düştügüne göre kamuda gereğinden fazla istihdam yaratıliyor olabilir. Yani kamu sektörü işsizliği düşürmek adına gizli işsizliği desteklemekte, bu gelişme üretkenliğin düşmesi ve KBGSKD'nin gerilemesi ile sonuçlanabilmektedir.

Analizi bölgelere göre sabit etki model tahmini yaparak sürdürdügümüzde, modelin açıklama gücü yani düzeltilmiş $\mathrm{R}^{2}$ 'si artmakta ve $0,95^{\prime} \mathrm{e}$ ulaşmakta ve YUKTOP, MTOTOP, YUKISG, ISTKY T değişkenleri istatistiki olarak anlamlı sonuçlar vermektedir. Sonuçlara bakıldığında tıpkı panel analizde olduğu gibi ISTKYT dişındaki tüm değişkenlerde beklenen yönde işaretlerin elde edildiği görülmektedir. Örneğin, YUKTOP değişkeninde meydana gelen 1 birimlik artış KBGSKD’nin 462 birim artmasına katkı sağlamaktadır. Aynı şekilde MTOTOP değişkeninde yaşanan benzer bir artış da bağımlı değişkeni 11.690 birim artırmaktadır. YUKISG değişkeninde meydana gelen 1 birimlik artış ise KBGSKD'yi 1.916 birime yakın bir düzeyde artırmaktadır.

Kişi başına düşen gayrisafi katma değerdeki farkl1lığı açıklamak için kullanılan modelin ortaya çıkardığı otonom gayrisafi katma değerin zamana göre değişip değişmediğini ortaya çıkarabilmek amacıyla bir sonraki adımda zamana göre sabit etki modeli kullanılmıştır. Zamana göre sabit etki modelinin açıklama gücü bölgelere göre sabit etki modeline göre daha düşüktür. Elde edilen sonuçlara göre bu analizde OGRBOGR, YUKTOP, MTOTOP, YUKISG, 50IST, ISTKYT, YOLALN değişkenleri istatistiki bakımdan anlamlıdır ve ISTKYT değişkeni de dahil olmak üzere hepsinin de işareti beklenenle uyumludur. Bu değişkenlerde meydana gelen bir iyileştirme kişi başına gayri safi katma değer üzerinde olumlu etki yaratmakta ve söz konusu değişkeni artırmaktadır.

Tablo 6. Panel Analiz Sonuçları,

\begin{tabular}{|c|c|c|c|c|c|c|c|c|c|c|c|c|}
\hline \multicolumn{3}{|c|}{$\begin{array}{l}\text { Örneklem: 2004-2011 } \\
\text { (dengeli): } 208\end{array}$} & ay- & sit & \multicolumn{5}{|c|}{ Yatay kesit: 26} & \multicolumn{3}{|c|}{ Toplam veri } \\
\hline \multicolumn{13}{|c|}{ Bağımlı değişken: $K B G S K D$} \\
\hline & & & & & \multicolumn{4}{|c|}{ Bölgelere göre sabit etki } & \multicolumn{4}{|c|}{ Zamana göre sabit etki } \\
\hline $\begin{array}{l}\text { Bağğmsız } \\
\text { değiskenler }\end{array}$ & & t-stat & $\mathbf{P}$ & & Katsay1 & t-stat & $\mathbf{P}$ & & Katsayı & t-stat & $\mathbf{P}$ & \\
\hline Sabit & $1.648,96$ & 1,71 & 0,09 & & $-3.756,15$ & $-5,39$ & 0,00 & & $1.113,14$ & 0,96 & 0,34 & \\
\hline OGRBOGR & $-117,13$ & $-6,18$ & $\overline{0,00}$ & *** & & & & & $-119,86$ & $-4,55$ & 0,00 & $* * *$ \\
\hline YUKTOP & 0,03 & 6,02 & $\overline{0,00}$ & *** & 0,03 & 2,45 & 0,02 & ** & 0,03 & 4,44 & 0,00 & *** \\
\hline MTOTOP & 9,18 & 4,25 & 0,00 & *** & 66,17 & 15,89 & 0,00 & **** & 5,60 & 2,34 & 0,02 & ** \\
\hline
\end{tabular}




\begin{tabular}{|c|c|c|c|c|c|c|c|c|c|c|c|c|}
\hline YUKISG & $47.941,11$ & 12,17 & 0,00 & $* * *$ & $15.816,22$ & 3,85 & 0,00 & $* * *$ & $43.961,65$ & 10,76 & 0,00 & \\
\hline 50IST & $9.462,43$ & 5,12 & 0,00 & ${ }^{* * *}$ & & & & & $11.712,25$ & 5,65 & 0,00 & \\
\hline TESBAS & 12,64 & 2,24 & 0,03 & $* *$ & & & & & & & & \\
\hline ISTKYT & $-3.143,73$ & $-3,20$ & 0,00 & $* * *$ & $-3.544,58$ & $-5,12$ & 0,00 & $F^{* * *}$ & $5.058,83$ & 3,57 & 0,00 & \\
\hline YOLALN & 23,15 & 3,13 & 0,00 & $F^{* * * *}$ & & & & & 21,01 & 2,75 & 0,01 & \\
\hline $\mathbf{R}^{2}$ & 0,87 & & & & 0,95 & & & & 0,84 & & & \\
\hline $\begin{array}{l}\text { Düz. } \mathbf{R}^{2} \\
\end{array}$ & 0,87 & & & & 0,95 & & & & 0,83 & & & \\
\hline Regr. St.Ht. & $2.163,53$ & & & & $1.022,29$ & & & & $1.814,35$ & & & \\
\hline F-stat & 172,32 & & & & 129,83 & & & & 70,91 & & & \\
\hline 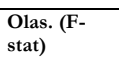 & 0,00 & & & & 0,00 & & & & 0,00 & & & \\
\hline
\end{tabular}

\#: Ekonometrik tahminlerde kullanılan veri tabanı istenildiği takdirde okuyucuya gönderilebilir.

Tablo direkt tahmin sonuçlarını vermektedir. Farklı birimlere sahip değişkenlerin hesaplanmış birim etkileri Ekler'de Tablo E4'te verilmektedir.

***, **: sırasıyla $\% 1$ ve $\% 5$ istatistiki anlamlılık düzeyi.

Sabit etkinin bölgeler ve y1llar arasındaki farklılaşma değerleri Tablo E3'ten izlenebilmektedir.Otonom gayrisafi katma değer en yüksek TR32 bölgesinde gerçekleşirken bunu TRB2, TR42, TR52, TR63 ve TR62 bölgeleri takip etmektedir9 . Analiz dönemi 2004-2011 içerisinde 2006-2009 ara dönemi otonom gayrisafi katma değer önemli ölçüde farklılık gösterdiği yıllardır ${ }^{10}$.

Değişkenlerin birim etkileri ise Tablo E4'te yer almaktadır. Öğretmen başına öğrenci sayısının (OGRBOGR) 1 birim artırılması durumunda tüm bölgelerin ortalama kişi başına reel katma değerinin 2489 birim azaldığ görülmektedir. YUKTOP değişkenindeki 1 birimlik artış tüm bölgelerin ortalama kişi başına reel katma değerini 462 birim artırırken, MTOTOP değişkenindeki 1 birimlik artış 989 birim iyileştirmektedir. Bu sonuç ara ve teknik elemanın önemini ortaya koyması bakımından önemlidir. Eğitim değişkenleri açısından en yüksek birim etki YUKISG değişkeni tarafindan ortaya koyulmaktadır. Bu değişkendeki 1 birimlik artış tüm bölgeler için kişi başına ortalama reel katma değerde 5.325 birim artış sağlamaktadır. Ölçekteki 1 birimlik artış 50IST tüm bölgelerdeki ortalama reel kişi başına gayri safi katma değeri 2.045 birim artırması, ortalama maliyetlerdeki azalmanın önemli etkisini göstermektedir. Yenilik değişkeni olarak modele dahil edilen TESBAS

9 TR10, TR33, TR51, TR83, TR90 Bölgelerinde kişi başına otonom gayri safi katma değer Türkiye ortalamasından düşüktür.

102010 ve 2011 yılları dışında tüm yıllarda kişi başına otonom gayri safi katma değer Türkiye ortalamasindan düşüktür. 
değişkeninin gayri safi katma değer üzerindeki birim etkisi göreli olarak düşüktür. Her 1 birimlik kamu yatırımının yarattığı istihdamın 1 birim artırılması bütün bölgelerde ortalama reel kişi başına gayri safi katma değeri 1.086 birim arttırmaktadır. Bu değişken için yıllara göre sabit etki modelinde bulunan bu katsayının işareti önceki modellerle tutarsızdır. YOLALN değişkenindeki 1 birimlik artış ise tüm bölgelerde ortalama reel kişi başına gayri safi katma değeri 994 birim yükseltmektedir, yani altyapı olanaklarının genişlemesinin katma değere etkisi pozitif olmaktadır.

Çalısmada farklı ekonometrik yöntemler ile cevap aradığımız sorulara ilişkin şu değerlendirmeler yapılabilir:

- Düzey 2 Bölgeleri'nde kişi başına düşen gayri safi katma değerdeki değişimi açıklamak için kullanılan modelin hem 2004 hem de 2011 yıllarında aynı/yakın açıklama gücüne sahip olduğu saptanmıştır.

- Düzey 2 Bölgeleri arasında değişen etkiye sahip bulunan değişkenlerin 2004 ve 2011 yıllarında aynı olup olmadığı araştırılmışır. Ölçek değişkenin (50IST) iki yılda da değişen etkiye sahip olduğu saptanmıştır. MTOTOP değişkenin iki yılda da değişen etkiye sahip olmadığı ve OGRBOR değişkeninin sadece 2011 yllında bölgeler bazında değişen etkiye sahip olduğu bulunmuştur.

- Otonom gayri safi katma değer hem yillar hem de Düzey 2 Bölgeleri arasında farkll11k göstermektedir.

\section{Sonuç}

Ülke içinde işgücü piyasası ve sosyal sermaye açısından var olan bölgelerarası farklılaşma, bölgesel verimlilik üzerine önemli etkilerde bulunmaktadır. Kişi başına gayri safi katma değer ile ölçülebilen bölgesel verimlilikteki farklılaşmanın ekonomiyi orta gelir tuzağına sürüklediği ileri sürülmektedir. Ekonomilerin orta gelir düzeyine yakınlaşması ile mevcut teknoloji giderek eskirken, tarımdan kentlere işgücünün transferi ortaya çıkmakta ve sermaye yatırımlarının uyardığ1 yüksek oranlı karlara dayanan büyüme kaynakları gücünü yitirmektedir (Yeldan vd., 2012). Bu nedenle, ilgili yazında ülke ekonomilerinin büyümek için üretkenliğinin artırlması gerekliliğine vurgu yapılarak beşeri sermayeyi geliştirecek yatırımlara ve ar-ge çalışmalarına öncelik verilmesi gerekliliği belirtilmektedir.

Bölgeler arasinda gerçekleşen işgücü ve sermaye göçü, bölgelerin birbirlerine finansal olarak bağımlı olmaları, ulaştırma ağlarının karmaşı1k yapılaşması gibi nedenler "ikili tuzak" yapısı ortaya koyarak ülkeleri yoksulluk tuzağına hapsetmektedir (Yeldan vd., 2012). Bu nedenlerle yoksul bölgelerde katma değer üretkenliğinin azalması ülke gelirinin azalmasına yol açmakta, yoksul ve orta gelirli bölgeler arasındaki açık büyümektedir. Giderek derinleşen bu bölgesel farklılık, büyüme hızının yavaşlamasını da beraberinde getirmektedir. Bu noktada, ülkenin tek bir homojen bölge olarak ele 
alınmaması gerekliliğ̈i, her bölge için kendi dinamiklerine ve özelliklerine göre ayrı politikaların uygulanması zorunluluğu ortaya çıkmaktadır.

Bölgesel farklılaşmanın orta geliri etkileyen verimlilikle ilişkisini ortaya koymayı amaçlayan bu çalşsmada ilk olarak ülke genelinde kişi başı gayri safi katma değeri açılayan faktörler ve etkileri tespit edilmeye çalışılmıştır. Daha sonraki adımda ise ülke genelinde etkili bulunan faktörlerin, etkileri açısından bölgeler arasında farklılık gösterip göstermediği araştırılmıştır.

Tahmin edilen panel modelinin sonuçlarına göre kişi başına gayri safi katma değerdeki değişimi açılamak için etkili olduğu öngörülen faktörlerin bu değişimi önemli ölçüde açıkladığı saptanmıştır. Söz konusu faktörlerin işgücü piyasası, eğitim, altyap1 ve yenilik ile ilgili olduğu düşünüldüğünde, oluşturulacak iktisadi politikaların da bu alanları iyileştirmeye yönelik olması gerektiği anlaşılmaktadır. Örneğin, brüt okullaşma oranını artırmayı amaçlayan politikalardan ziyade okullarda öğretmen başına düşen öğrenci sayısını azaltmaya çalışmak, bir başka ifade ile her seviyede okul sayısını artırmak daha etkili olabilecektir. Benzer şekilde mesleki ve teknik okul sayısının artırilmasına yönelik politikalar hem sanayide ara ve teknik eleman açığının kapanmasına yol açacak hem de yine kişi başına gayri safi katma değerin artırilmasına etki edebilecektir. Ampirik bulgulara bakıldığında mesleki ve teknik okul sayısının kişi başına gayri safi katma değer üzerindeki pozitif etkisinin yükseköğretim mezunlarına göre daha yüksek olduğu görülmektedir. Yükseköğretim mezunlarının etkisinin katma değere pozitif yansıması ancak söz konusu mezunlara istihdam olanaklarının yaratılması ile mümkün olabilecektir. Belki de Türkiye'de şu anda işgücü piyasasında üniversite mezunu işsizlerin sayısının sürekli artması da bu sorunun bir yansimasidir.

Türkiye'de KOBI'lerin gelişmesi için uygulanan politikaların doğru ve hala geçerliliğini korumakta olduğu anlaşılmaktadır. Nitekim üretim ölçeği $(50+$ işyeri ölçeğinde istihdam edilenlerin toplam istihdama oranı),kişi başına gayri safi katma değer üzerinde en büyük ikinci etkiye sahip faktör olarak belirlenmiştir. Her türlü fiziki iktisadi faaliyetin (reel) gerçekleştirilebilmesi için gerekli olan altyapı olanaklarının (yol, ulaşım, nakliye vs.) varlığ kişi başı gayri safi katma değerin artırılması açısından önemini korumaktadır. Altyapıya ilişkin ilginç bir bulgu ise kamu yatırımlarının yarattı̆̆ istihdamın gayri safi katma değer üzerinde beklenen pozitif etkiyi göstermemesidir. Bunun sebebini iki şekilde düşünmek mümkün olabilir: Ortaya çıkan bu durum, daha çok altyapı yatırımlarına yönelen kamu sektörünün ya verimliliği düşürecek şekilde aşırı istihdama yönelmesi ya da kamunun mevcut istihdamı sabit tutarken altyapı yatırımlarından zaman içinde çekilmesi ile gerçekleşebilir.

İnovasyon göstergesine ilişkin etkinin gayri safi katma değer üzerinde göreli daha az önemli olması, inovasyonun tescili alınmış patent miktarı ile 
ölçüldüğü göz önüne alındığında, gerçekleştirilen inovasyonun seri üretime geçmemiş olmasından ya da üretim sürecine hiç girmemiş olmasından kaynaklanabileceği söylenebilir. Sonuçta, patenti alınmış yeni bir ürünün üretim sürecine geçmesi için sabit sermaye yatırımlarının yapılması gerekmektedir. Türkiye'nin gayri safi yurtiçi hasıla içinde sabit sermaye paylarına bakıldığında uzun süreden beri artış gösteremediği görülmektedir.

Türkiye genelinde gayri safi katma değerdeki değişimi açıklayan faktörlerin Düzey 2 bölgeleri bazındaki etkileri incelendiğinde üç faktör öne çımaktadır: İşyeri ölçeğinin büyüklüğü, mesleki ve teknik okulların fazlalı̆̆ ve öğretmen başına düşen öğrenci sayısının düşüklüğü. Bu faktörler hem tüm bölgelerde etkili olmakta hem de dönem başı ve dönem sonunda (2004-2011) etkisini sürdürmektedir.

İşyeri ölçeği etkisine bakıldığında ise 2004 yllında bu değişkenin göreli olarak daha gelişmiş ve daha batıda yer alan bölgelerde gayri safi katma değeri artırmak yönünde etkili olduğu görülmektedir. Az gelişmiş bölgelerde, göreli olarak da Doğu ve Güneydoğu bölgelerinde, çok etkili değildir. İstihdamın ve yatırımların nispi olarak ülkenin batısında yığılmış olduğu dikkate alındığında, bu sonuç beklenenle uyumludur. Ancak uygulanacak politikaların amacı bölgesel eşitsizliği gidermek ise uygulamaların daha çok doğu bölgelerine dönük olması gerekecektir. 2011 yllına gelindiğinde ise bu faktörün katma değer üzerindeki etkisi açısından bölgesel farklılaşmanın ortadan kalktı̆̆1 görülmektedir. Dolayısı ile 2004-2011 periyodunda ülke genelinde uygulanan teşvik politikalarının başarılı olduğu söylenebilir.

Mesleki ve teknik okulların kişi başına gayri safi katma değer üzerindeki etkileri değerlendirildiğinde, 2004 yllında bölgesel bazlı bir farklılaşma saptanamamıştır. Ortaöğretimde öğretmen başına öğrenci sayısının gayri safi katma değer üzerindeki etkisi 2004 yllında bölgesel olarak bir farklılaşma göstermezken, 2011 yllında etkisi açısından bölgeler arasında küçük de olsa bir fark vardır. Ayrıca 2011 yılına gelindiğinde bu değişkenin nispeten daha gelişmiş ve daha batıda bulunan bölgelerde gayri safi katma değeri artırmak yönünde etkili olduğu söylenebilir. Ancak az gelişmiş bölgelerde, özellikle de doğu ve güneydoğu bölgelerinde çok etkili olmadığ görülmektedir. Yani, nüfusun yığıldığı bölgelerde bu faktör daha etkilidir ve şayet doğu ile batı bölgeleri arasındaki fark kapatılmak isteniyorsa, politikaların doğuya yönelmesinde fayda olacağ1 söylenebilir. Dönemin tamamı (2004-2011 periyodu) incelendiğinde bu faktörün etkileri açısından bölgelerin birbirinden uzaklaştı̆̆ görülmektedir.

Otonom gayri safi katma değerin göreli olarak daha az gelişmiş bölgelerde pozitif ve daha büyük çıkması bu bölgelerde daha düşük etkili çıkan açıklayıcı faktörler ile bir tutarlılık göstermektedir. 


\section{Kaynakça}

Aiyar, S., Duval, R., Puy, D., Wu, Y., Zhang, L. (2013) Growth Slowdowns and the Middle-Income Trap, IMF Working Paper, WP/13/71.

Alçın, S., Güner, B. (2015) Orta Gelir Tuzağ1: Türkiye Üzerine Bir Değerlendirme, Marmara Üniversitesi İ̈BF Dergisi, XXXVII (1), 27-45.

Brunsdon, C., Fotheringham, A.S., Charlton, M.E. (1996) Geographically Weighted Regression: A Method for Exploring Spatial Nonstationarity. Geographical Analysis, 28 (4), 281-298.

Çavuş, Z. (2014) Orta Gelir Tuzağı: Türkiye Örneği, İnönü Üniversitesi Sosyal Bilimler Enstitüsü Yayınlanmamış Yüksek Lisans Tezi, Malatya.

Eichengreen, B. (2011) "Escapingthe Middle Income Trap", http://www.kansascityfed.org/publicat/sympos/2011/Eichengree n_final.pdf.

Eichengreen, B., Park, D., Shin, K. (2011) When Fast Growing Economies Slowdown: International Evidenceand Implicationsfor China, NBER Working Paper Series, 16919. May.

Eichengreen, B., Park, D., Shin, K. (2013) Growth Slowdowns Redux: New Evidence On The Middle Income Trap, NBER Working Papers Series, 18673, January.

Fangcai, F. (2012) Is There A 'Middle-Income Trap? Theories, Experience Sand Relevanceto China, China\&World Economy, 20(1), 49-50.

Felipe, J., Abdon, A., Kumar U. (2012) Trackingthe Middle-Income Trap: What Is It, Who Is In It, And Why?, Levy Institute Of Bard College Working Paper, 715, New York.

Flaen, A., Ghani, E., Mishra, S. (2013) How to Avoid Middle Income Traps? Evidencefrom Malaysia, World Bank Policy Research Working Paper, No:6427.

Fotheringham, A. S., Brunsdon, C., Charlton, M. (2002) Geographically Weighted Rregression: The Analysis of Spatially VaryingRelationships. Chichester, Willey.

Gürsel, S., Soybilgen, B. (2013) Türkiye Orta Gelir Tuzağmm Eşiğginde, BETAM Yayınları, No: 13/154.

Kurtoğlu, Y. (2014) Orta Gelir Tuzağından Çıkış, Ekonomik Yaklaşım, 25(90), 71-90. 
Lee, K. (2013) Schumpeterian Analysis Of Economic Catch-Up: Knowledge, PathCreation and the Middle-Income Trap, Cambridge: Cambridge University Press,.

OECD. (2013) Avoidingthe Middle-Income Trap: Policies for Sustained and Inclusive Growth. http://www.oecd.org/china/China-Brochureeng-September2013.pdf

Paus, E. (2013) Globalization and Middle Income Trap: A Capabilities-Based Approachwith Focus on Latin America, In UNDP, Ministry of Foreign Affairs, Korea Institute for International Economic Policy. 2013. Challenges of The Middle-Income Countries. Seoul Debates 2013. Seoul: UNDP, Mofa, Krep, 59-63.

Taşç1, K., Özsan, M. E. (2014) Türkiye'de Bölgeler İtibarılyla Orta Gelir Tuzağı, İsveren, 52(2), 51-57.

Tho, T. V. (2013) The Middle-Income Trap: Issues for Members of The Association of Southeast Asian Nations, ABDI Working Paper Series, No: 421. May.

TÜíK.

Temel

İstatistikler, http://www.tuik.gov.tr/UstMenu.do?metod=temelist

Tuncel, C. O. (2014) Orta Gelir Tuzağı ve İnovasyon Politikaları: Doğu Asya Deneyimi Ve Türkiye İçin Dersler, Maliye Dergisi, 167, TemmuzAralık, 40-70.

Yeldan, E., Taşçı K., Voyvoda E., Özsan, M.E. (2013) Orta Gelir Tuæağından Çıkıș: Hangi Türkiye, Cilt 2: Bölgesel Kalkınma Ve İkili Tuzaktan Çıkış Stratejileri, Türkiye Girişim ve $\dot{I}_{s}$ Dünyası Konfederasyonu (TURKONFED), İstanbul.

Yeldan, E., Taşçı K., Voyvoda E, Özsan, M.E. (2012) Orta Gelir Tuæağından Çıkıș: Hangi Türkive, Cilt 1: Makro/Bölgesel/Sektörel Analiz, Türkiye Girişimve Iș Dünyası Konfederasyonu (TURKONFED), İstanbul.

Yiping, H., Gou, Q., Wang X. (2013) Institutionsandthe Middle-Income Trap: Implications of Cross-Country Experiences for China, Conference On China, Inequality, Growthand Middle-Income Trap, China Economic Research Center, July 1-2, 2013, Beijing.

Woo, W. T. (2012) China Meetsthe Middle Income Trap: The Large Potholes in the Road to Catching-Up, Journal Of Chinese Economic and Business Studies, 10(4), 313-336.

World Bank.(2013) World Development Report 2013, http://data.worldbank.org. 


\section{Ekler}

\section{Tablo E1. 2004 Y1lı Lokal Tahmin Katsayıları}

\begin{tabular}{|l|r|r|}
\hline & $\mathbf{5 0 I S T}$ & Lokal R \\
\hline TR10İstanbul & 0,20 & 0,86 \\
TR21Tekirdağ, Edirne, Kırklareli & 0,21 & 0,89 \\
TR22Balıkesir, Çanakkale & 0,21 & 0,89 \\
TR31İzmir & 0,21 & 0,89 \\
TR32Aydın, Denizli, Muğla & 0,21 & 0,90 \\
TR33Manisa, Afyon, Kütahya, Uşak & 0,06 & 0,93 \\
TR41Bursa, Eskişehir, Bilecik & 0,18 & 0,83 \\
TR42Kocaeli, Sakarya, Düzce, Bolu, Yalova & 0,20 & 0,88 \\
TR51Ankara & 0,21 & 0,90 \\
TR52Konya, Karaman & 0,21 & 0,89 \\
TR61 Antalya, Isparta, Burdur & 0,20 & 0,84 \\
TR62Adana, Mersin & 0,19 & 0,92 \\
TR63Hatay, Kahramanmaraş, Osmaniye & 0,16 & 0,93 \\
TR71 Kırıkale, Aksaray, Niğde, Nevşehir, Kırşehir & 0,21 & 0,90 \\
TR72 Kayseri, Sivas, Yozgat & 0,17 & 0,93 \\
TR81 Zonguldak, Karabük, Bartın & 0,21 & 0,91 \\
TR82 Kastamonu, Çankıı, Sinop & 0,21 & 0,94 \\
TR83 Samsun, Tokat, Çorum, Amasya & 0,15 & 0,94 \\
TR90 Trabzon, Ordu, Giresun, Rize, Artvin, Gümüşhane & 0,10 & 0,94 \\
TRA1 Erzurum, Erzincan, Bayburt & 0,05 & 0,93 \\
TRA2 Ağrı, Kars, Iğdır, Ardahan & 0,07 & 0,93 \\
TRB1 Malatya, Elazı̆g, Bingöl, Tunceli & 0,05 & 0,93 \\
TRB2 Van, Muş, Bitlis, Hakkari & 0,05 & 0,93 \\
TRC1 Gaziantep, Adıaman, Kilis & 0,12 & 0,93 \\
TRC2 Şanlıurfa, Diyarbakır & 0,03 \\
TRC3 Mardin, Batman, Şırnak, Siirt & 0,03 & 0,93 \\
min. & 0,21 & 0,92 \\
mak. & & 0,83 \\
& 0,94 \\
\hline
\end{tabular}


Tablo E2. 2011 Y11 Lokal Tahmin Katsayıları

\begin{tabular}{|l|r|r|r|}
\hline & OGRBOGR & $\mathbf{5 0 I S T}$ & $\begin{array}{r}\text { Lokal } \\
\mathbf{R}^{2}\end{array}$ \\
\hline TR10 İstanbul & $-0,14$ & 0,20 & 0,88 \\
TR21 Tekirdağ, Edirne, Kırklareli & $-0,14$ & 0,20 & 0,89 \\
TR22 Balıkesir, Çanakkale & $-0,14$ & 0,20 & 0,89 \\
TR31 İzmir & $-0,14$ & 0,20 & 0,88 \\
TR32 Aydın, Denizli, Muğla & $-0,14$ & 0,19 & 0,89 \\
TR33 Manisa, Afyon, Kütahya, Uşak & $-0,12$ & 0,20 & 0,87 \\
TR41 Bursa, Eskişehir, Bilecik & $-0,14$ & 0,20 & 0,88 \\
TR42 Kocaeli, Sakarya, Düzce, Bolu, Yalova & $-0,14$ & 0,19 & 0,88 \\
TR51 Ankara & $-0,14$ & 0,19 & 0,88 \\
TR52 Konya, Karaman & $-0,14$ & 0,19 & 0,88 \\
TR61 Antalya, Isparta, Burdur & $-0,14$ & 0,19 & 0,87 \\
TR62 Adana, Mersin & $-0,13$ & 0,19 & 0,89 \\
TR63 Hatay, Kahramanmaraş, Osmaniye & $-0,12$ & 0,19 & 0,88 \\
TR71 Kırıkkale, Aksaray, Niğde, Nevşehir, Kırşehir & $-0,13$ & 0,19 & 0,89 \\
TR72 Kayseri, Sivas, Yozgat & $-0,13$ & 0,19 & 0,88 \\
TR81 Zonguldak, Karabük, Bartın & $-0,14$ & 0,19 & 0,88 \\
TR82 Kastamonu, Çankırı, Sinop & $-0,13$ & 0,20 & 0,89 \\
TR83 Samsun, Tokat, Çorum, Amasya & $-0,12$ & 0,20 & 0,88 \\
TR90 Trabzon, Ordu, Giresun, Rize, Artvin, Gümüşhane & $-0,12$ & 0,20 & 0,88 \\
TRA1 Erzurum, Erzincan, Bayburt & $-0,12$ & 0,20 & 0,88 \\
TRA2 Ağrı, Kars, Iğdır, Ardahan & $-0,12$ & 0,21 & 0,88 \\
TRB1 Malatya, Elazı̆̆, Bingöl, Tunceli & $-0,12$ & 0,20 & 0,87 \\
TRB2 Van, Muş, Bitlis, Hakkari & $-0,12$ & 0,21 & 0,88 \\
TRC1 Gaziantep, Adıyaman, Kilis & $-0,12$ & 0,19 & 0,87 \\
TRC2 Şanlıurfa, Diyarbakır & $-0,12$ & 0,20 & 0,87 \\
TRC3 Mardin, Batman, Şırnak, Siirt & $-0,12$ & 0,21 & 0,88 \\
\hline min. & & 0,19 & 0,87 \\
mak. & 0,21 & 0,89 \\
\hline
\end{tabular}




\section{Tablo E3. Sabit-Etkiler: Bölgeler ve Y1llar}

\begin{tabular}{|c|c|c|c|c|}
\hline & Bölgeler & & Yillar & \\
\hline TR10 & İstanbul & $-12.113,9$ & 2004 & $-2574,3$ \\
\hline TR21 & Tekirdağ, Edirne, Kırklareli & $8.627,7$ & 2005 & $-1650,4$ \\
\hline TR22 & Balıkesir, Çanakkale & $2.322,8$ & 2006 & $-781,3$ \\
\hline TR31 & İzmir & $-332,5$ & 2007 & $-293,6$ \\
\hline TR32 & Aydın, Denizli, Muğla & 68,7 & 2008 & 792,7 \\
\hline TR33 & Manisa, Afyon, Kütahya, Uşak & $-5.114,6$ & 2009 & 470,7 \\
\hline TR41 & Bursa, Eskişehir, Bilecik & $-3.049,5$ & 2010 & 1375,7 \\
\hline TR42 & Kocaeli, Sakarya, Düzce, Bolu, Yalova & 659,8 & 2011 & 2660,4 \\
\hline TR51 & Ankara & $-5.789,5$ & & \\
\hline TR52 & Konya, Karaman & $-756,1$ & & \\
\hline TR61 & Antalya, Isparta, Burdur & $2.458,1$ & & \\
\hline TR62 & Adana, Mersin & $-803,2$ & & \\
\hline TR63 & Hatay, Kahramanmaraş, Osmaniye & $-788,7$ & & \\
\hline TR71 & Kırıkkale, Aksaray, Niğde, Nevşehir, Kırşehir & $1.426,8$ & & \\
\hline TR72 & Kayseri, Sivas, Yozgat & $-2.463,3$ & & \\
\hline TR81 & Zonguldak, Karabük, Bartın & $6.843,7$ & & \\
\hline TR82 & Kastamonu, Çankırı, Sinop & $3.438,9$ & & \\
\hline TR83 & Samsun, Tokat, Çorum, Amasya & $-3.867,3$ & & \\
\hline TR90 & Trabzon, Ordu, Giresun, Rize, Artvin, Gümüşhane & $-7.372,3$ & & \\
\hline TRA1 & Erzurum, Erzincan, Bayburt & $3.377,8$ & & \\
\hline TRA2 & Ağrı, Kars, Iğdır, Ardahan & $4.120,8$ & & \\
\hline TRB1 & Malatya, Elazı̆̆, Bingöl, Tunceli & $2.556,5$ & & \\
\hline TRB2 & Van, Muş, Bitlis, Hakkâri & 526,0 & & \\
\hline TRC1 & Gaziantep, Adıaman, Kilis & $2.324,3$ & & \\
\hline TRC2 & Şanliurfa, Diyarbakır & $1.841,5$ & & \\
\hline TRC3 & Mardin, Batman, Şırnak, Siirt & $1.857,3$ & & \\
\hline
\end{tabular}


Ümit K. SEYFETTİNOĞLU, Mehmet ZANBAK

Tablo E4. Değiş̧kenlerin Birim Etkileri

\begin{tabular}{|l|l|r|r|r|}
\hline & Tanım & $\begin{array}{r}\text { Panel } \\
\text { Model }\end{array}$ & $\begin{array}{r}\text { Sabit } \\
\text { Etki- } \\
\text { Bölge } \\
\text { Model }\end{array}$ & $\begin{array}{r}\text { Sabit } \\
\text { Etki-Yı1 } \\
\text { Model }\end{array}$ \\
\hline OGRBOGR & öğretmen başına düşen öğrenci oranı & -2432 & & -2489 \\
YUKTOP & ön lisans ve lisans mezun sayısı & 462 & 462 & 462 \\
MTOTOP & meslek ve teknik okul sayısı & 1622 & 11690 & 989 \\
YUKISG & yükseköğretim mezunlarının toplam işgücü & 5807 & 1916 & 5325 \\
50IST & içindeki oranı & 4652 & & 2045 \\
TESBAS & 50+ işyerlerindeki istihdamın toplam & 155 & & \\
işindeki oranı & patent tescilinin toplam başvuruya oranı & -675 & & 1086 \\
YOLALN & her 1 TL'lik kamu yatırımının yarattığ1 & 1095 & 761 & 994 \\
& istihdam & & & \\
\hline
\end{tabular}

